\title{
The Development of Legal Databases in Refugee Work
}

\author{
HANS THOOLEN*
}

\begin{abstract}
Today's information technology can be used to improve the legal protection of refugees, by providing information relevant to the asylum procedure, and laying the foundation for progressive development at the international level. The positive potential of legal databases is only now beginning to be realised, thanks to pioneering efforts within human rights and related documentation centre networks. UNHCR is helping to set up a case law database, in co-operation with non-governmental organizations. A database on national legislation is also planned, as is a full text database of international legal instruments database. Legal literature continues to be covered by the database REFLIT (REFugee LITerature) of UNHCR'S Centre for Documentation on Refugees (CDR/UNHCR). This article examines two basic kinds of information-retrieval systems, 'free text', and 'indexed', and considers their different structures, uses and search procedures, with reference to work on a forthcoming refugee thesaurus. The author calls attention to the need for standard formats, such as those of HURIDOCS, and to problems of scope and coverage. He suggests that information and documentation are areas in which practical co-operation between the $\mathrm{UN}$, governments and non-governmental organizations could be implemented to advantage.
\end{abstract}

\section{Introduction: the need}

'Information on all aspects of human rights is essential to the universal protection and promotion of human rights. The rapid increase of interest in human rights coincides with the rapid development of information technology. Unless a common and universal system of communication is evolved, valuable information will be wasted, existing international machinery will not

- LL.M, Leiden State University, Netherlands. Chief, Centre for Documentation on Refugees, Office of the United Nations High Commissioner for Refugees, Geneva, Switzerland (CDR) UNHCR). The views expressed are the personal views of the author, and are not necessarily shared by the United Nations or UNHCR. 
function, standards and codes agreed between governments and within professional bodies will not become known and their implementation will not be monitored.'

This is how Martin Ennals, way back in 1982 at the first Assembly of the HURIDOCS-network, ' masterfully summarized the need for all concerned with human rights to devote more of their time, energy and resources to concerted action, so as better to cope with the challenges posed by the increasing availability of information technology.

Similar ideas were expressed recently by the Editor-in-Chief of this Journal, when he stated that 'refugee law cannot develop in the abstract, but only on the basis of facts and within the society which it will serve. Information will assist that process, the formulation of policies, more systematic determination of the well-foundedness of claims to protection, identification of those who require special measures of protection and the rapid initiation of solution-oriented programmes.' At the same time he pleaded for the increased use of the resources of the existing system. 'Universal and regional forums, human rights commissions, supervisory and adjudicative institutions, national courts and tribunals-all can be exploited in creative recourse to the potential of human rights. In this way, the persecuted and the displaced may be effectively protected now, and the groundwork established for future development of the law'.

It would indeed seem that enhanced information work in the refugee law area serves the dual purpose of improving the legal protection of refugees in the present situation at the national level, for example, by providing refugee lawyers with access to information relevant to their work in an asylum procedure, and laying the foundation for a progressive development of refugee law at the international level.

In spite of occasional failures and widespread under-utilization of existing database resources, electronic publishing of legal data is expanding continuously. Much of it is has the objective of conquering or maintaining market segments, but there is also real profit to be made in selling legal databases, as the huge Lexis/Nexis service of Mead Data Central in the USA demonstrates. In Western Europe, developments are slower, but legal information systems are now available in most

\footnotetext{
1 HURIDOCS stands for HUman Rights Information and DOCumentation Systems, a worldwide network with the objective of improving access to, and dissemination of, public information on human rights, through more effective, appropriate and compatible methods and techniques of information-handling. To this end it has given high priority to the development and introduction of standard formats for the recording of human rights information, starting with a series of formats for bibliographic material; see Stormorken B., HURIDOCS Standard Formats for the Recording and Exchange of Information on Human Rights, Dordrecht, Martinus Nijforf, 1985, ISBN 90247-3187-9. The Secretariat of the network is located at: Langesgate 6, 0165 Oslo I, Norway.

${ }^{2}$ Goodwin-Gill, G.S., 'The Future of International Refugee Law,' REFUGEES, No. 57, October 1988 , p. 29.
} 
European countries, from either private or state-owned suppliers. Of course, together with human rights, peace, women's issues and development, the refugee world belongs to the so-called 'soft sector' when it comes to the number of potential users who are willing or able to pay for information services. However, the advantages of legal databases still stand, and the relative weakness of access to information in the existing manual systems is all the more reason for making an effort to introduce information technology. Anyway, if the profit element dominated the question, non-profit organizations would not even have telephones.

\section{Legal database plans in the area of refugees}

The legal profession has not generally been the first to embrace information technology, and initial encounters were often limited to the, admittedly important, aspect of the protection of the right to privacy. ${ }^{3}$ Lawyers in the refugee community are no exception, and only recently has there been a surge of interest in the positive potential of legal databases.

Some of these developments took place outside the refugee area but in related fields, such as human rights; others were well within a specific refugee context, but outside the Office of the United Nations High Commissioner for Refugees (UNHCR). In Western Europe, examples of the first category are the Council of Europe and the Netherlands Institute of Human Rights (SIM), ${ }^{4}$ while the ELENAgroup of the European Consultation on Refugees and Exiles (ECRE), ${ }^{5}$ and the database ASYLDOC of the German-based institute ZDWF, ${ }^{6}$

3 With regard to data protection, UNHCR is conducting an internal study, with a view to developing a policy in line with proposed United Nations guidelines concerning computerized personal datafiles; see statement by UNHCR to the 40th session of the Subcommission on Prevention of Discrimination and Protection of Minorities, agenda item 11: UN doc. E/CN.4/ Sub.2/1988/SR.23, para. 20.

+ Since 1983 the Council of Europe has been developing a legal database containing the full text of the international treaties relevant to the protection of human rights in Western Europe, the rules of procedure of the organs of the European Convention on Human Rights, and the rulings of those organs; the latter cover the Judgments of the European Court of Human Rights, the Resolutions of the Committee of Ministers discharging its functions under the Convention, the Reports of the European Commission on Human Rights, and the Decisions on Admissibility of the Commission. In 1982, both the Council of Europe and the Netherlands Institute for Human Rights (SIM) were developing plans for a parallel collection of national case law concerning the European Convention on Human Rights. Since 1986, these plans have been put on the backburner for the time being.

3 ELENA stands for European LEgal Network on Asylum. It was established in 1984 as a subsecretariat of ECRE (European Consultation on Refugees and Exiles), to be a network of lawyers active in asylum procedures who, inter alia, exchange information and, in particular, recent case law from their own country or region. ELENA has decided to make ZDWF in Bonn (see following note) the focal point for the collection, treatment and re-dissemination of such case law.

6 ZDWF stands for Zentrale Dokumentationstelle der Frcien Wohlfahrtsplege fur Flüchllinge c.V. It is a non-governmental documentation centre, largely funded from government sources in the Federal 
are illustrations of the latter. In the United States of America, no projects for legal databases on human rights in general or refugees in particular are known to the author; this may be due to the fact that national legal databases are relatively well developed, but refugee lawyers on both sides of the ocean have now started regular consultations in a trans-Atlantic dialogue.

Partly inspired by these developments, partly in response to its own concrete needs, the Division of Refugee Law and Doctrine of UNHCR has now developed a number of projects, which include the following databases: (a) case law; (b) national legislation; (c) international instruments; and (d) State practice. The last one, based to a very large extent on reports from UNHCR's feld offices, will be of a completely internal character. The first three, however, will contain mostly public material and are potentially sharable with other users.

UNHCR has allocated first priority to the establishment of the case law database, which will contain references to, and excerpts from, the most important legal decisions affecting refugees. As with literature, even with the active support of UNHCR's field offices, it would be a Herculean task to collect and prepare all of the data; co-operation with non-governmental organizations (NGOs) - which had already started consultations among themselves-seemed to be the logical answer. After agreement had been reached on the standard formats to be used in the exchange of data, a contract with the German refugee documentation centre ZDWF in Bonn was concluded in 1988. Selected cases will be collected from the ELENA NGO-network and other sources, and sent to UNHCR after translation and treatment. A copy of the data will remain with ZDWF for inclusion in its database ASYLDOC, which is available on-line for any user through the host DIMDI. ${ }^{7}$

The database on national legislation will contain references to (rather than the the full text of the laws and regulations directly relevant to the status and treatment of refugees and asylum-seekers. As this concerns a large variety of legal instruments from many countries, often in national languages, it is not presently envisaged to add excerpts or summaries of the documents to the references in the database, but only to use it for quick retrieval of pertinent texts held in a manual system. It is planned to feed in the full text to the international legal instruments database, as well as all the information on ratifications and

Republic of Germany. Since 1981 it has worked on establishing a database combining literature and case law references, mostly in German. Is database $A S Y L D O C$ can be consulted off-line through ZDWF (P.O Box 301069, 5300 Bonn 3); or on-line through the host DIMDI (sce following note).

7 DIMDI, the German Institute for Medical Documentation and Information, is host to several databases, including $A S Y L D O C$. For further information regarding on-line access, contact DIMDI, PO Box 420580, 5000 Köln 41, Federal Republic of Germany; tel. 888 1364; telex. 47241 . 
accessions, and the text of any reservations and declarations made by the States Parties. What matters most for this particular database is its compatibility with (if not integration into), other similar databases in the United Nations system.

Finally, legal literature continues to be covered by the database REFLIT (REFugee LITerature) of UNHCR's Centre for Documentation on Refugees (CDR/UNHCR), ${ }^{8}$ providing a basis for following the development of doctrine. Care has been taken to ensure, as far as possible, that the case law and legislation databases follow similar formats, standards and procedures, thereby ultimately allowing combined searches through the different types of documents.

Together with the country-by-country database on State practices and the as yet insufficiently accessible but rich archives, these databases will form UNHCR's institutional memory in protection. What is most needed to make these plans a reality, is to give priority in the allocation of always scarce resources to the preparation of high quality data, and to the provision of computer support and staff training. Co-operation with governments, non-governmental organizations and individual lawyers will have to be strengthened through information and documentation networks. ${ }^{9}$ The success or failure of these efforts, however, will probably depend most on whether the enthusiasm of those who have to co-operate in the creation of the databases (UNHCR staff and non-governmental organizations) can be sustained by providing them soon with access to operational and reliable knowledge. A coherent and realistic policy for access to the databases, be it on-line or off-line, will therefore have to be developed as a matter of urgency.

The remainder of this essay focusses on the case law database, in light of the experience of the Council of Europe in its efforts to establish a database of national case law relating to the European Convention of Human Rights. The reason for this alignment is not so much that most legal battles on refugee law are fought in Western Europe, although it is true that the legal procedures for the determination of refugee status in Europe and North America are older and more elaborate than in other parts of the world. The reason is rather that 'international case law' as

\footnotetext{
${ }^{8}$ The Centre for Documentation on Refugees (CDR) is UNHCR's central documentation office for public material concerning refugees. It became part of UNHCR in April 1986, with the merger of three pre-existing small centres. Its mandate is, first, to provide information support to staff members of UNHCR; secondly, to provide (more limited) documentary services to outside users; and thirdly, to co-ordinate a world wide network of information and documentation centres. Its database REFLIT contains 5,550 items in English, French and Spanish.

${ }^{9}$ A group of twenty-seven governmental and non-governmental organizations, meeting in Bergisch-Gladbach, Federal Republic of Germany in November 1986, recommended that an international network of refugee documentation centres be established, and that UNHCR be requested to assume the co-ordinating function. In June 1987 UNHCR accepted initial responsibility for these efforts, and a network co-ordinator was appointed in the CDR.
} 
such is missing with regard to refugees; ${ }^{10}$ legal decisions are taken at the national level, with no possibility of appeal to an international refugee body, other than through the existing international human rights machinery. An illustration of the latter point is the use that can be made of Article 3 of the European Convention, forbidding torture, cruel and inhuman treatment, and which is also recognized as embodying the non-refoulement principle. ${ }^{11}$

The High Commissioner has a monitoring role with regard to the application of the 1951 Convention, as stated in Article 35, paragraph 1 and the Preamble. The absence of a specific judicial or quasi-judicial body at the international or regional level in no way diminishes the need for quick access to case law. On the contrary, the absence of such a final court of appeal makes it increasingly difficult for UNHCR and lawyers in refugee cases to trace individual decisions, and to determine whether in any country the courts have pronounced themselves on a specific point of law of relevance to the protection of refugees. The frequent rotation of UNHCR staff between field offices and headquarters further reduces the possibility of following case law developments, and strengthens the call for a more systematic approach.

\section{Basic features of electronic information retrieval in refugee law}

There are usually two kinds of legal information needs that a system could address: the need for factual information (for example, the date of a law, the conditions for appealing a decision, the text of an article); and the need for reference information (for example, a bibliography on a certain subject, a listing of articles that might be relevant).

There are also two kinds of information-retrieval systems, often but not necessarily following the distinction made above); one is called 'free text', and the other 'indexed'. In the latter, vocabulary is controlled by a limited list of mandatory terms, from which terms (keywords) have to be assigned to a document in the database; when the controlled list is structured, it is called a thesaurus. UNHCR, at the request of a large number of NGOs and with the support of the Canadian International

$10 \mathrm{Cr}$. Thoolen, H., 'Towards a Digest of International Human Rights Caselaw: A Proposal for Co-operation,' SIM-Newsletter, No I4/15, August 1986, pp. 15-16.

"See, for example, Kälin, W., 'Drohende Menschenrechtsverletzungen im Heimatstaat als Schranke der Rückschiebung gemāss Art. 3 EMRK', 1986 Zeitschrift für Ausländerrecht and Austanderpolitit (ZAR), No. 4, pp. 172-178; Vogler, T., 'The scope of extradition in the light of the European Convention on Human Rights,' in Matscher and Peahold, eds., Protection of Human Rights: the European Dimension, 1988, pp. 663-671; Carillo, J.A., 'The European Convention on Human Rights and the Asylum-secker,' in Council of Europe, The Law of Asylun and Refugets: Present Tendencies and Future Perspectives, 1987, pp. 27-44 (proceedings of the 16th Colloquy on European Law, 1986, Lund, Sweden). 
Development Research Centre, is currently engaged in a multilingual refugee thesaurus project, which should be finished by April 1989. ${ }^{12}$

It is also possible to let every word occurring in the document be an index term, which would then be searchable. This is called 'free text' retrieval. In such systems, the full text of a document, or an elaborate summary (abstract), is fed into the system, which stores each word (except so-called stopwords, such as it, him, her, she, he, they, should, because, etc., which may make up $40 \%$ of a text) in an 'inverted file', i.e. an alphabetical order of terms.

The differences between the two methods are considerable, but cannot be discussed in any detail in this article. ${ }^{13}$ Legal texts are often needed for quotation, however, and databases containing legislation, international instruments and legal decisions, should preferably contain the text itself, rather than someone else's summary. From having the full text available in the system, with the possibility of reproducing it on screen or paper, it is only a small step to making it freely searchable, given the low cost of computer storage today, and the performance of modern search tools (for example, Boolean operators, such as AND, OR, NOT and ANDNOT; and 'proximity operators', which enable the user to specify how close one word should occur to another). Documents are increasingly produced in machine-readable form, through the use of word processors, the cost of making abstracts is unlikely to go down, and legal databases in the foreseeable future can be expected to be based on full-text systems.

On the other hand, in the refugee law context, we are talking about legal decisions made in a large variety of countries in many different languages; the cost of translation, certainly of the full text, is likely to be prohibitive. Also, the authority of foreign decisions is limited in most legal systems, and this further weakens the justification for investment in translation and computer storage space. For the time being, the refugee case law database will be limited to a structured database: a specific number of fields; keywords; and a large fixed field called "abstract", containing a summary of the facts, a short summary of the decision and, in most cases, an excerpt of the most relevant parts of the legal reasoning. The legal decisions represented in the Cases and Comments section of this Journal illustrate this approach.

This leaves unresolved the question of lack of access to the source document, which is the more serious in the specialized area of human

12 Acuña, S., 'Multilingual Refugee Thesaurus,' Rafuger Abstracts, v. 7, no. 2, June 1988, pp. 1-4 (Foreword).

13 Council of Europe, Human Rights Documentation Centre, Directorate of Human Rights, The relevarace of computers to the legal profession and their ase withen the network of national correspondents, 1986, pp 1-22 (Doc. no.: DH-CD (86) 5). This paper was prepared by the then Head of the Documentation Centre, Bjorn Stormorken, for the first meeting of national correspondents, Strasbourg, 24-25 November 1986. 
rights and refugees, where conventional law library facilities are not very well developed. Simultaneous development of a good delivery service among the main documentation centres should therefore be an important feature of the international refugee documentation network.

\section{Agreements needed in establishing a refugee case law database}

\subsection{Standards}

The Council of Europe has a network of national correspondents, which used to supply annually a large amount of unstructured information on national developments with regard to the European Convention on Human Rights, mostly in the form of photocopies of case law, literature and legislative developments. These raw data were hard to interpret and treat, and in 1985, the Council sharpened the conditions of contract with national correspondents, by introducing a uniform standard format for reporting and recording of information, and requesting a synthesis in one of the official languages (French or English). With the benefit of that experience, UNHCR introduced much the same standard formats from the start of its database efforts, grafting on the accepted use of the HURIDOCS standard formats in the non-governmental refugee community. The use of common formats, which determine the underlying data structure rather than prescribe specific applications software, is of crucial importance to any collaborative effort in information-handling, and is likely to become better understood as an increasing number of organizations and individuals in the refugee area get computerised.

However much the necessary pre-conditions for recording and exchange are fulfilled, important problems of substance remain to be resolved. $^{14}$

\subsection{Scope}

The first question is that of scope. A user will find it hard to assess the relevance of the database as such, unless its content is well defined, in terms both of what it covers and what it does not cover; this is called the principle of 'the best possible contrast'. In addition, a user will want to know the exact extent of coverage of the information contained in the database, in order to allow a certain type of source to be eliminated from the list of those to be consulted; this is called the principle of 'exhaustive coverage'. Both principles are under strain in the refugee law field.

\footnotetext{
it See op. cit., above note 13, in particular for the question of 'contrast' and 'coverage', borrowed from pp 14-17; the document contains much more detail relevant to the creation of legal databases.
} 
The definition of who is a refugee, as opposed to an asylum-seeker, has not been authoritatively settled, despite a 38-year-old international convention; regional definitions also differ from that in the 1951 Convention. Moreover, recognized refugees and asylum-seekers - in different degrees - enjoy many of the rights and freedoms of nationals. Does this mean that all legal decisions which could have an impact on the rights and freedoms of refugees have to be included? This question has to be addressed with some urgency, and any temptation to fll the database as quickly as possible with cases relevant to refugees has to be resisted; limiting the database to those who are recognized as refugees would be totally insufficient, and would beg the very question of the refugee determination procedure. Consequently, the documentation area might be tentatively defined as the totality of cases in which a claim to be a refugee is made, or where the refugee-claiming capacity is a legal issue at stake. The term 'refugees' should be understood in its broadest sense, comprising asylum-seekers who are granted permission to stay under a different title. Moreover, insofar as that is not yet completely covered, the database should contain decisions which interpret provisions of the applicable international instruments, or analogous provisions of domestic law.

\subsection{Coverage}

Coverage of the above area will become even more problematic, if all decisions by all courts and administrative organs at all levels are included. The sheer numbers would be impossible to scan in most countries, while those to be treated and included in the database would exceed the capacity of even the best-equipped centre. In addition, published cases are few in number, (not even one percent in most European countries), and obtaining copies of other decisions directly from the courts would require further scanning efforts. One obvious solution would be to limit the coverage of the case law database to certain types of courts or tribunals, or to those at a certain level, for instance, appellate decisions having precedent effect. Depending on the legal system, however, lower court cases may be important in breaking new legal ground, or in assessing a factual situation in a way that has important consequences for other refugees and asylum-seekers in the same situation. Such decisions are often more common in the refugee area than elsewhere, while many rulings by administrative bodies also have strong precedent-setting impact.

It is therefore difficult to develop a simple set of straightforward selection criteria, to be used by a variety of legal workers in different countries. The first meeting of national correspondents of the Human Rights Documentation Centre of the Council of Europe, 24-25 November 1986, spent most of its time refining and agreeing selection criteria. 
The result was a compromise between the limitation based on a courtlevel approach (all Convention-related decisions by the highest courts); and the definition of relevance in legal human rights terms (for example, all those decisions that refer expressly to the Convention). Even then, a large measure of discretion was left to individual correspondents to include other cases as well. ${ }^{15}$

There seems to be no escape. A large measure of freedom must be left to those selecting cases, although in the long run this may reduce the usefulness of the database. It risks covering too many areas only partly, and being biased towards certain countries, not for objective reasons, but because of the selection criteria employed by the correspondent. The best solution may be to follow the developments closely, be aware of the dangers, test the database on exhaustion and coverage, and bring together the principal correspondents as soon as possible to review the results and refine the criteria further if necessary.

\subsection{Networking}

Information and documentation generally are emerging as one area in which practical co-operation between the United Nations, governments and non-governmental organizations could be best implemented to mutual benefit. Refugee law is no exception. Besides the use of common standard formats and terminology (which seem to be on their way as described above), this co-operation will require the development of network skills and routines, as well as the holding of joint training courses for documentalists and lawyers alike. Agreed instruction manuals will have to be developed and maintained.

Other questions relating to decentralized data preparation must also be addressed by the members of a network, which involves the most important actors. Some questions seem to be minor at first sight, but may become crucial at a later stage, when the number of items in the database is such that corrections are difficult to make. These include the appropriateness of legal terms in the thesaurus, the quality of translation, and the agreement on abbreviations. ${ }^{16}$

\subsection{Access}

Although there are several ways in which an electronic database may improve the conventional flow of information in the area of refugee law

is Council of Europe, Directorate of Human Rights, Summan Report of First Meeting of National Correspondents, 24-25 November 1986, Strasbourg (Doc. no: DH-CD (86) 7), in particular Appendix III.

${ }_{16}$ The Centre for Documentation on Refugees (CDR) has submitted to the thesaurus working group a standard list of unique abbreviations for the basic international refugee law instruments, combining short abbreviations with the last 2 digits of the year they were adopted. For example, the 1969 OAU Convention Governing the Specific Aspects of Refugee Problems in Africa would read: 'OAUR69'. 
(through such off-line services as print-outs; publication of surveys and updates; library cards, etc.), the most intriguing question is whether and how public on-line access can be ensured. In addition to obstacles created by the existence of different query-languages and the insufficiency of telecommunications in many parts of the world, there is the question of access to the database host (in particular when the host is a UN-agency) and of copyright of the data. The latter problem arises in particular when downloading of the database in whole or in part becomes possible in an on-line situation. These issues need to be discussed by the main actors on the basis of expert advice. For the time being, the solution sought by UNHCR is to have a copy of the case law database available in an outside organization, which in turn makes it available to the public on a non-profit basis.

Above all, decision-making with regard to information-handling in the various organizations concerned with the protection of refugees needs to be given a higher priority than has hitherto been the case. The beneficial potential of legal databases, as well as the practically irreversible nature of many initial decisions with regard to scope, coverage and access, warrant the urgent attention of those whose responsibility is the legal protection of the refugees.

\section{Résumé}

On peut avoir recours à l'informatique pour améliorer la protection juridique des réfugiés en fournissant une information relative à la procédure d'asile et en jetant les bases d'un développement progressif du droit au niveau international. On commence tout juste à réaliser le potentiel de bases de données juridiques, grâce aux efforts de pionniers travaillant dans le domaine des droits de l'homme et des réseaux de documentation y afferents. Le HCR contribue à l'établissement d'une base de données en matière de jurisprudence, en coopération avec les organisations non gouvernementales. Une base de données sur la législation nationale est également prévue, ainsi qu'une base de données complètes sur les instruments juridiques internationaux. La littérature juridique continue d'être entrée dans la base REFLIT (REFugee LITerature) du Centre de documentation sur les réfugiés (CDR/HCR). Cet article examine deux systèmes de recherche de l'information, que les textes soient indexés ou non, et examine leurs structures d'utilisation et procédures de recherche différentes en relation avec le travail mené à bien pour la publication prochaine d'un thésaurus sur les réfugiés. L'auteur attire l'attention sur la nécessité d'une présentation standard, telle que celle de HURIDOCS, et sur les problèmes de portée. Il estime que l'information et la documentation sont des domaines où la coopération pratique entre les Nations Unies, les organisations gouvernementales et non gouvernementales doit être mise à profit. 


\section{Resumen}

La informática de hoy permite mejorar la protección legal de los refugiados, proporcionando información relacionada con el procedimento de asilo y sentando las bases para su desarrollo progresivo a nivel internacional. El real potencial de un banco de datos jurídicos está empezando a valorarse, merced a los esfuerzos pioneros en el ámbito de los derechos humanos y en la red de centros de documentación relacionada al tema. El ACNUR contribuye al establecimiento de un banco de datos para casos jurisdiccionales, en cooperación con las organizaciones no gubernamentales. También se preve la creación de un banco de datos de legislación nacional, como incluso un banco de datos de textos integrales de instrumentos legales internacionales. La documentación legal consta en el banco de datos REFLIT (REFugee LITerature) del Centro de Documentación sobre Refugiados del ACNUR (CDR/ACNUR). Este articulo examina dos tipos básicos de sistemas de búsqueda de información: 'texto libre', y 'por indice', y considera sus distintas estructuras, usos y procedimientos de búsqueda, en el contexto del diccionario especializado sobre terminologia respecto a refugiados. El autor hace hincapié en la necesidad de utilizar formatos comunes, como los de HURIDOCS, y se refiere a problemas de contexto y alcance. Propone que la información y la documentación sean áreas en donde la cooperación práctica entre las Naciones Unidas, los gobiernos y las organizaciones no gubernamentales se vea favorecida. 